\title{
Determinants of Investments in the Nigerian Economy: An Empirical Approach (1990 - 2013)
}

\author{
Duruechi Anthony H. ${ }^{1}$ \& Ojiegbe Joe N. Ph.D ${ }^{1}$ \\ ${ }^{1}$ Department of Banking \& Finance, Imo State University, Owerri, Nigeria \\ Correspondence: Duruechi Anthony H., Department of Banking \& Finance, Imo State University, Owerri, Nigeria.
}

Received: September 1, 2015

Accepted: September 30, $2015 \quad$ Online Published: October 14, 2015

doi:10.5430/ijfr.v6n4p217

URL: http://dx.doi.org/10.5430/ijfr.v6n4p217

\begin{abstract}
This study examined the determinants of investments in the Nigerian Economy: An Empirical Approach, 1990-2013. The unsteady behaviour of investment in Nigeria has become a source of worry to all who are concerned about the growth of the country. Also, decisions whether to invest or not are constrained by numerous factors that must be identified and accorded due consideration in order to foster investments. In an attempt to achieve the objective, hypotheses were formulated and data for the study collected from the Central Bank of Nigeria Statistical Bulletin. The collected data were analyzed using E-view 7.1 statistical package in line with the OLS model. The Unit root test conducted with the Augmented Dickey Fuller (ADF) Unit root revealed that the variables were stationary at first difference rate 1(1). The existence of long-run relationship between investments, inflation rate, government expenditure, exchange rate and Interest rate were established with the Johansen Co-integration test. The Pairwaise granger causality shows causality running unidirectionaly from government expenditure to investment. The error correction model (ECM) indicated that short run disequilibrium in investments can be corrected at the speed of $67 \%$ per annun. These simply show that there is a significant relationship between the selected macroeconomic variables and level of investment in Nigeria. Also postulated by the study is the fact that only government expenditure has a significant influence on investment in Nigeria thus leading the study to conclude that investment in Nigeria is still at a very low level and should be encouraged to impact positively on the economy in general. Government should review her policies on investments and pay more attention to its determinant i.e. inflation rate, exchange rate, government expenditure and interest rate. They are essential ingredients for boosting investments in Nigeria.
\end{abstract}

Keywords: investments, determinants, economy, approach

\section{Introduction}

Investment is the commitment of resources made with the hope of realizing benefits which are expected to occur over a reasonably long period of time. It is an economic activity where an individual, group or government buys assets with the hope of receiving adequate risk premium (returns) overtime.

According to Vaish (2007) investment is the change in capital stock during a period. Consequently, unlike capital, investment is a flow and not a stock term. This means that capital is measured at a point in time, while investment can only be measured over a period of time. Investment is a net tangible property of human being and of institutional arrangement capable of rendering services to consumers and producers of a nation (Ogoke, 2002). This implies the profitable postponement of consumption to the future. Such greater consumption expectation is only attained if the resources committed yield benefits as per the opportunity cost of the capital. It could also mean the production of capital goods: goods which are not consumed but instead used in future production.

Ideally, investments exist in two forms; namely: capital (real) and financial investment. Capital investment concerns itself with tangibles which convenants and crystallize into projects or collection of assets, single assets or fixed assets such as machines, building etc. This, in other words, is also total expenditure on new plant and equipment that is mostly taken with the aim of reducing cost and producing goods to generate future benefits. On the other hand, financial investment refers to investment in securities such as shares, bonds, financial instruments that are referred to as "IOUs", documents of claims economic agent have on others.

Investment plays important role in functioning of an economy whether developed or underdeveloped. Economic growth of most economies is derived from investment in such economy. No wander investment is seeing as a 
propellant of economic growth. To this end, measures are taken by government of various countries of which Nigeria is not an exception to encourage investment so as to boost high productivity, innovation, employment level, standard of living, reduce poverty level and ultimately accelerate economic growth (Ayeni, 2014). Investment in various sectors of the economy stimulate aggregate employment output, demand income which also increase the government revenue for the provision of basic industrial and agricultural inputs towards the growth and development of any economy. This entails that investment multiplier increase national income which in turn increases savings for investment, consumption and aggregate demand level. The effect will be the rising standard of living of the citizenry.

Ali and Mshelia (2007) observed that investment is the most strategic factor influencing growth in any country. It is characterized as the main key to increased level of productivity. A strong correlation between investment and economic growth has been revealed by both theoretical and empirical studies by development economists of the world (Adofu, 2010). Similarly, Muhammad and Mohammed (2004) noted that investment plays a very important and positive role for progress and prosperity of any country. Many countries rely on investment to solve their economic problem such as poverty, unemployment, etc. Development economics in offering insights into the determinants of growth affirmed that the importance and role of investment cannot be overemphasized as it contributes meaningfully to economic growth (Nnanna O.J., Englama and Odoko, 2004).

However, Bage (2003), writing on Asian countries experience suggest that an investment rate of between $20 \%$ and $25 \%$ could engender growth rate of between 7 and 8 percent with adequate attention on such factors that affect or may affect investment and its trends.

No doubt, there are so many factors (internal and external) that influence investment. This therefore means that for a developing country like Nigeria to attain the goal of economic growth, amongst other economic objectives, there is need to increase the tempo of investment that would lead to higher economic growth with much focus on such factors that determine investments within and outside the national economy.

\subsection{Statement of the Problem}

Investment is the mainstream of economic development of any nation. Ajakaiye (2002) observed that Nigeria has been classified as low savings and even lower investment economy. It is based on this fact that one of the principal objectives of the Nigeria government is fostering sustained economic growth through the promotion of enabling investment environment. Stimulation of sustained economic growth requires a balance between investment and such factors that affect investment.

The unsteady behaviour of investment in Nigeria has become a source of worry to all who are concerned about the growth of the country. The low level of investment has appeared to be the major problem facing the economy. Despite policies made by the government of Nigeria at different times to tackle the problem, the menace still persists. According to Johnson (2002), successive governments have implemented policies and strategies to raise the level of investment but these policies so far have been erratic. It has however, been found that a major problem is that government is so much concerned about policies to boost investment without much knowledge or investigations of the determinants of investment (Ajaikaiye 2002).

Decisions whether to invest or not are determined and/or constrained by numerous factors. These factors must be identified and importance of identified variables as policy instruments lies in the fact that they can be used judiciously to foster investments. An analysis of investment requires a simultaneous link to those factors and other unique variables that equally react to fluctuations. Attempts to analyse investment determinants and predict its behaviour in the Nigerian economy have achieved a disproportionate share of analysts' attention.

Decisions taken in respect of investment, whether rightly or wrongly have a lasting effect on the growth and development of an economy. To avoid the danger of faulty investment or investment decisions, it is necessary to examine or investigate very carefully those factors or macroeconomic variables that determine investments in the Nigerian economy, with a view to knowing their impact.

\subsection{Objectives of the Study}

The main objective of this paper is to identify and examine those macroeconomic variables that determine investment in Nigeria, with a view to knowing their impact. Specific objectives are to:

1) determine whether inflation rate has significant impact on the level of investment in Nigeria.

2) ascertain the impact of exchange rate movement on the level of investment.

3) determine whether government expenditure influences the level of investment, and 
4) examine the effect of interest rates on investments in Nigeria.

\subsection{Research Questions}

This is meant to provide answers to the under listed questions:

1) What is the effect of inflation rate on the volume of investment in Nigeria?

2) How has the exchange rate movement impacted on the amount of investment undertaken in the economy?

3) What impact does government expenditure have on the level of investment in the Nigeria's economy?

4) What impact does interest rate movements have on investments in the Nigerian economy?

\subsection{Research Hypothesis}

The research is based on the following hypotheses which were tested:

$\mathrm{H}_{\mathrm{ol}}$ : Inflation rate has no significant effects on the level of investment in Nigeria

$\mathrm{H}_{02}$ : Exchange rate movement has no significant influence on the level of investment in Nigeria

$\mathrm{H}_{03}$ : Government expenditure has no significant impact on the amount of investment in Nigeria.

$\mathrm{H}_{04}$ : There is no significant correlation between interest rate movement and the level of investment in Nigeria.

\subsection{Scope of the Study}

In order to make this research work extensive and manageable, it covers a period of twenty four (24) years (1990 2013). Within this period, various inflation, exchange rate, government expenditure profiles and interest rate policies were examined against the corresponding investment using available published data.

\section{Review of Related Literatures}

\subsection{Conceptual Issues}

Investment is generally classified into four major components: the private domestic investment, the public domestic investment, the foreign direct investment and portfolio investment. Private domestic investment refer to gross fixed capital formation plus net changes in the level of inventories whereas public investment includes investment by government and public enterprises on social and economic infrastructure, real estate and tangible assets. The combination of private investment and public investment is normally referred to a Gross Fixed Capital Formation. The foreign investment, when it is on tangible asset, is referred to as Foreign Direct Investment (FDI). It is called portfolio investment when it is on shares, bonds, securities, etc (Bakare 2011).

Prior to the Structural Adjustment programme, Nigeria was operating more of a socialist mixed economy in which government owned and controlled most public enterprises. However, with the introduction of IMF/ World Bank backed Structural Adjustment Programme in July 1986, the nation is now more or less capitalist with major public enterprises either privatized or commercialized. Before now, Nigeria has implemented several national and economic development rolling plans. These plans are woven around some specific objectives which include: increase in the real income of average citizen, reduction in unemployment level, increased sectoral and regional balanced development, stimulate high level of dependence on use of local resources in the achievement of growth, economic stability etc. World Bank and Chenery (1961) observed that all development models have come to accept that the rate of development of an economy is determined by the accumulation of physical and human capital, the efficiency of resource use and the ability to acquire and apply modern technology (investment).

Investments are critical to economic growth that will lead to rapid economic development and reduce poverty (Nnanna et al 2004). In any way one may look at it, economic growth and development indicate the ability of an economy to increase production of goods and services with the stock of capital and other factors of production within the economy. It is therefore assumed that a high level of capital accumulation, with the right combination of other factors of production will bring about higher output and growth. Economic growth and development are theoretically and empirically established to be dependent on capital accumulation or investment.

Investment is an essential component of aggregate demand and fluctuations in investment have considerable effect on economic activities and long-tern economic growth (Serven and Solinano, 2000). As a key to growth, it is reflected in the development strategies and plans of many countries.

One of the critical objectives of investment, according to Okereke (2000), is social optimization which includes achieving a target market share, and maintenance of minimum level of employment. 
Nigeria with a population of over 140 million, vast mineral resources and favorable climate and vegetation features, has the largest domestic market in Sub-Saharan Africa. The domestic market is large and potentially attractive to domestic and foreign investment as attested to by portfolio investment inflow of over N1.0 trillion into Nigeria through the Nigerian Stock Exchange (NSE) in 2003 (CBN, 2003). Investment outcome however, has not been encouraging. It was observed that aggregate investment expenditure, as a share of GDP grew from $16.9 \%$ in 1970 to a peak of $29.7 \%$ in 1976 before declining to an all time low of $7.7 \%$ in 1985 . Thereafter, the highest was $11.75 \%$ of GDP in 1990, before declining to $9.3 \%$ in 1994. Beginning from 1995, investment GDP ratio declined significantly to $5.8 \%$ and increased marginally to $6.99 \%$ in 1997 and remained there about till 2001 when $6.95 \%$ was recorded on the average of about four-fifth of the Nigeria's national output consumed annually. In comparison with both slow and fast growing economies, Nigeria's Investment ratio lags behind the required minimum average of about $20 \%$ of GDP annually that propelled the growth rate of those economies (World Bank, 1996). For instance, in the South East Asian Countries, investment/GDP ratio is about 35\% in Singapore, 38\% in Korea and 41\% each in Malaysia and Thailand. Chile in South America registered 28\% (World Bank 1998). This explains the low growth rate of the Nigerian economy which closely followed the pattern of the growth rate of investment expenditure.

Donwa and Agbontaen (2010) observed that aggregate income levels between N128.6m to N297.8m in the early 1970, fell to as low as - N404.1 and - N334.7 million in the early 1980. Although in 1987, the levels of investment signs increased consistently and persisted till 2004, recording its highest income N258,388.6m in 2003, yet, from 2004, domestic investment witnessed a continuous decline which fell below any other level of loss ever recorded in this sector since independence with as low as N1921.2m in 2005 to as drastically low as N114,484.4 in the year 2008. The levels of investment especially domestic have fallen with over $145 \%$ below its 2004 position. Apparently, if investments remain at the current low level, it will slow down potential growth and reduce long-run levels of per-capita consumption and income, thus militating against the sustainability of economic growth and any hope of meaningful poverty alleviation (Iyoha 1998). Theoretically, it is expected that positive changes in macroeconomic adjustments are expected to trigger a significant resurgence of investment resulting from increases in capital performance and acceleration of investment flows. By and large, these promised benefits of macroeconomic adjustments have not materialized in Nigeria. Thus, it is necessary to appraise very carefully those factors that have influence in terms of the expected returns from investment.

\subsection{Theoretical and Empirical Literatures}

This study is based on the flexible version of the accelerator theory; a theory in economics that establishes a link between investment output and cost of capital. The theory states that the optimal or desired level of investment depends on the level of output and the use of cost of capital which in turn depends on the price of capital goods, the real rate of interest and the depreciation rate.

Investigating the determinants of investment, Lesotho (2006) employed the OLS multiple regression technique with variables such as real interest rate and credit to investors. Findings from the study revealed that real interest rate affect investment positively and significantly. Other variable(s) do not affect investment in the short term as they show insignificant co-efficient.

Sajid and Sarfraz (2008) investigated causal relationship between investment and exchange rate. The study used co-integration technique and vector error correction model to examine causality between investment and exchange rate. The result showed that there is long-run as well as a short run equilibrium relationship between them. However, the study was silent on the impact of exchange on investments.

Omoke and Ugwuanyi (2010) tested relationship between inflation, money supply and investment in Nigeria using Johansen Co-integration and Granger Causality test. The results suggest that price stability can contribute towards increased level of investment. The study found that major determinants of investment were monetary aggregates, real output, inflation and exchange rates. This study never considered the role government expenditure plays in the determination of investment level.

Mouyiwa (2005) examined the linkage between inflation rate and investment using panel co-integration approach and a variance decomposition. The result of the study was a negative relationship between inflation rates and investment.

Elbadawi (1996) confirmed the effect of inflation on economic growth and government expenditure on investment. He observed in his study that investment stimulates economic growth while government expenditure spurs investment. 
Aysam et al (2004) in their study "How to Boost Investment in the MENA Countries", used their independent variables to include real interest rate, macroeconomic stability, situation reform, external stability, macroeconomic volatility and physical infrastructure. Their study comprised panel of 40 developing countries. They used co-integration techniques to determine the existence of a long-term relationship between investment and its determinants. They found out that almost all the explanatory variables exhibit a significant impact on investment but higher interest rate (r) appears to exert a negative effect on investment.

Using a data from Nigeria, Ikhide (2004) did empirical study on external shocks, savings and investment. The econometric result indicated that growth of real income, increase in public expenditure and exchange rate, openness of the economy and high savings have positive effect on investment. Rising inflation and high interest (lending) rates equally impede investment in Nigeria.

On the basis of empirical consideration, De-gregorio (2009) suggested that in developing countries, investment is determined mainly by the level of interest rate, government expenditure, credit available for investment and exchange rate.

Anfofun (2005) investigated on the macroeconomic determinants of investment in Nigeria. He discovered that debt burden, inflation, exchange rate political crises and Coup d'etat negatively affect investment. The negative relationships attest to the major reasons why investors do not have confidence in Nigeria investment climate and such investors are scared away.

Most policies in recent times have been centered on how to improve the level of investment but as to what factors determine the level of investment in an economy seem to be a mirage.

\section{Methodology}

This study is to identify the macroeconomic variables that determine investment and examine the relationship with respect to level of investment and nature of impacts.

Time series data were obtained for the study covering the period of 1990-2013. The said data were sourced via the Central Bank of Nigeria Statistical bulletin 2013. Four determinants of investment were identified to estimate level of investment(s).

The statistical analysis used for data analysis was the E-view. The model specification used lies on the Ordinary Least Square (OLS) for multiple regression analysis. To ascertain the stationarity of the data, Augmented Dickey Fuller (ADF) Unit root test was conducted, Johansen co-integration analysis were employed to determine the existence of long run relationship while the Error Correction test was used to evaluate the speed of adjustments.

The model were specified thus:

$$
\mathrm{Inv}=\mathrm{F}(\mathrm{INF}, \mathrm{EXR}, \mathrm{GOVEX}, \mathrm{INT})
$$

Where:

$\begin{array}{ll}\mathrm{INV} & =\text { Investments } \\ \mathrm{INF} & =\text { Inflation Rate } \\ \mathrm{EXR} & =\text { Exchange Rate } \\ \text { GOVEX } & =\text { Government Expenditure } \\ \mathrm{INT} & =\text { Interest Rate }\end{array}$

In the OLS form, the above amounted to:

$$
\mathrm{INT}_{\mathrm{t}}=\mathrm{a}_{0}+\mathrm{a}_{\mathrm{i}} \mathrm{INF}_{\mathrm{t}}+\mathrm{a}_{0} \mathrm{EXR}_{\mathrm{t}}+\mathrm{a}_{\mathrm{B}} \mathrm{GOVEX}_{\mathrm{t}}+\mathrm{a}_{4} \mathrm{INT}_{\mathrm{t}}+\mathrm{U}_{\mathrm{t}}
$$

From the OLS model specification the linear OLS model for this study was given as:

$\mathrm{INV}_{\mathrm{t}}=\mathrm{a}_{0}+\mathrm{a}_{1} \mathrm{INF}_{\mathrm{t}}+\mathrm{a}_{2} \mathrm{EXR}_{\mathrm{t}}+\mathrm{a}_{3} \mathrm{GOVEX}_{\mathrm{t}}+\mathrm{a}_{4} \mathrm{INT}_{\mathrm{t}}$

\subsection{The A Priori Test Expectation}

An a priori argument, reason or probability is based on assumed principles or facts, rather than actual or observed fact. These in economic terms, are based on economic theory and they seek to determine whether the expected is equal to the observed, i.e. whether the economic expectations are in line with actual observations in the analysis. Therefore, from the OLS Linear equation, it was expected that the following conditions are obtainable: $a_{1}>0, a_{2}>0$, $a_{3}<0, a_{4}>0$ 


\title{
4. Presentation of Results and Interpretations
}

\author{
4.1 Unit Root Tests
}

Table 1. Summary of unit root test results

\begin{tabular}{lllllll}
\hline \multicolumn{2}{l}{ AUGMENTED DICKEY FULLER UNIT ROOT TEST } & & & & & \\
\hline VARIOUS & T - STATIC & CRITICAL & ORDER & OF & & \\
& & VALUE & INTEGRATION & & SIGNIFICANCE \\
\hline INV & -4.175592 & -3.769597 & $1^{\text {st }}$ Difference & $*$ & $*$ \\
INF & -3.795455 & -3.769597 & $1^{\text {st }}$ Difference & $*$ & $*$ & $*$ \\
EXR & -7.080726 & -3.769597 & $1^{\text {st }}$ Difference & $*$ & $*$ & $*$ \\
GOVEX & -10.97361 & -3.769597 & $1^{\text {st }}$ Difference & $*$ & $*$ & $*$ \\
INT & -6.279250 & -3.769597 & $1^{\text {st }}$ Difference & $*$ & $*$ & $*$ \\
\hline
\end{tabular}

Source: E-view 7.1 Researchers' computation 2015.

The unit root test was carried out using the Augmented Dickey fuller test in order to determine whether the data set is stationary and the order or integration. Evidently, from the above table all the variables turned out stationary at first difference 1(1); thus, meaning that the data set can be relied upon for the estimation.

\subsection{Cointegration Tests}

Table 2. Johansen co-integration test results

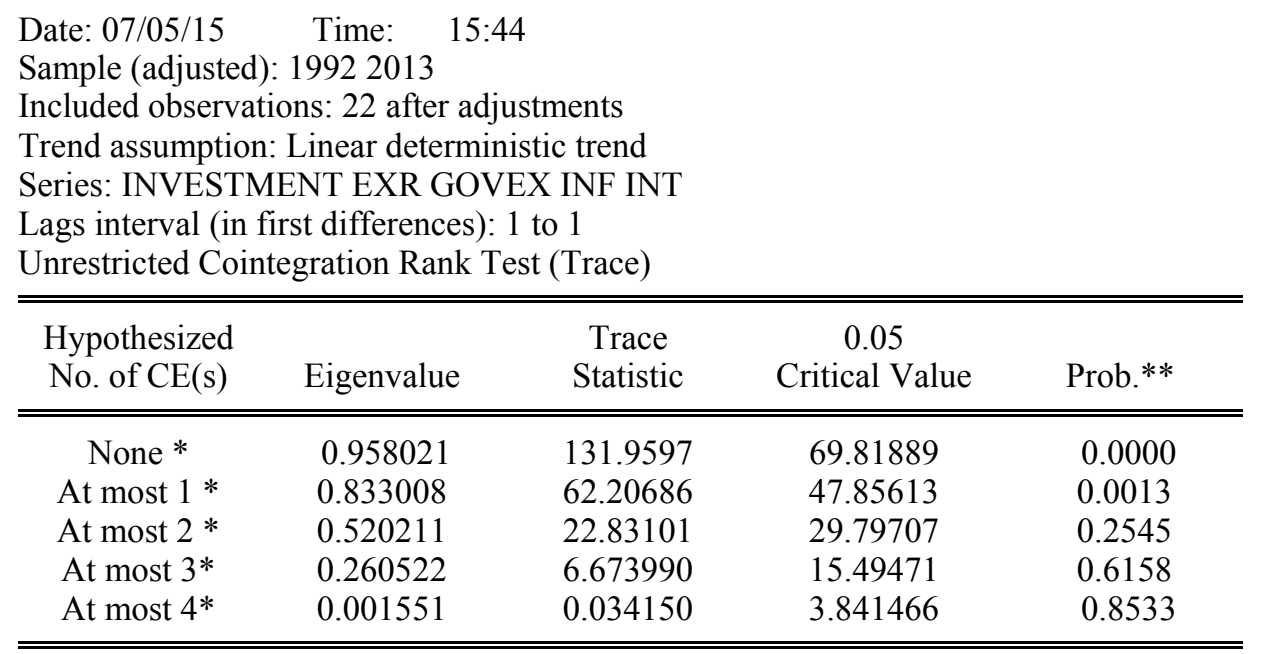

Trace test indicates 2 cointegrating eqn(s) at the 0.05 level

$*$ denotes rejection of the hypothesis at the 0.05 level

**MacKinnon-Haug-Michelis (1999) p-values

Unrestricted Cointegration Rank Test (Maximum Eigenvalue)

\begin{tabular}{ccccc}
\hline \hline $\begin{array}{c}\text { Hypothesized } \\
\text { No. of CE(s) }\end{array}$ & Eigenvalue & $\begin{array}{c}\text { Max-Eigen } \\
\text { Statistic }\end{array}$ & $\begin{array}{c}0.05 \\
\text { Critical Value }\end{array}$ & Prob.** \\
\hline \hline None ${ }^{*}$ & 0.958021 & 69.75283 & 33.87687 & 0.0000 \\
At most $1 *$ & 0.833008 & 39.37585 & 27.58434 & 0.0010 \\
At most 2* & 0.520211 & 16.15702 & 21.13162 & 0.2158 \\
At most 3* & 0.260522 & 6.639839 & 14.26460 & 0.5326 \\
At most 4* & 0.001551 & 0.034150 & 3.841466 & 0.8533 \\
\hline \hline
\end{tabular}

Max-eigenvalue test indicates 2 cointegrating eqn(s) at the 0.05 level

* denotes rejection of the hypothesis at the 0.05 level

**MacKinnon-Haug-Michelis (1999) p-values

Source: E-view 7.1 Researchers' computation 2015. 
Given the trace statistic ratios and the critical values for the hypothesized number of co-integrating equations, the test indicates the existence of only two (2) co-integrating equation at $5 \%$ level of significance. This confirms the existence of a long-run relationship between investments and the independent variables: inflation rate, exchange rate, government expenditure and interest rate.

\subsection{Granger Causality Tests}

Table 3. Pairwise Granger causality test results

Pairwise Granger Causality Tests

Date: 07/05/15 Time: 15:45

Sample: 19902013

Lags: 2

\begin{tabular}{|c|c|c|c|}
\hline Null Hypothesis: & Obs & F-Statistic & Prob. \\
\hline EXR does not Granger Cause INVESTMENT & 22 & 101930 & 0.3819 \\
\hline INVESTMENT does not Granger Cause EXR & & 0.00951 & 0.9905 \\
\hline GOVEX does not Granger Cause INVESTMENT & 22 & 3.92221 & 0.0398 \\
\hline INVESTMENT does not Granger Cause GOVEX & & 0.58954 & 0.5655 \\
\hline INF does not Granger Cause INVESTMENT & 22 & 0.16980 & 0.8452 \\
\hline INVESTMENT does not Granger Cause INF & & 0.29383 & 0.7491 \\
\hline INT does not Granger INVESTMENT & 22 & 1.43333 & 0.2659 \\
\hline INVESTMENT does not Granger Cause INT & & 2.27362 & 0.1333 \\
\hline GOVEX does not Granger Cause EXR & 22 & 0.09631 & 0.9087 \\
\hline EXR does not Granger Cause GOVEX & & 1.20643 & 0.3236 \\
\hline INF does not Granger Cause EXR & 22 & 3.22826 & 0.0648 \\
\hline EXR does not Granger Cause INF & & 8.17199 & 0.0033 \\
\hline INT does not Granger Cause EXR & 22 & 0.79586 & 0.4673 \\
\hline EXR does not Granger Cause INT & & 1.97417 & 0.1695 \\
\hline INF does not Granger Cause GOVEX & 22 & 0.76691 & 0.4799 \\
\hline GOVEX does not Granger Cause INF & & 0.76909 & 0.4789 \\
\hline INT does not Granger Cause GOVEX & 22 & 0.53482 & 0.5953 \\
\hline GOVEX does not Granger Cause INT & & 0.21534 & 0.8084 \\
\hline INT does not Granger Cause INF & 22 & 7.33930 & 0.0050 \\
\hline INF does not Granger Cause INT & & 1.33580 & 0.2892 \\
\hline
\end{tabular}

Source: E-view 7.1 Researchers' computation on 2015.

The above causality test conducted with a maximum lag of 2 shows that Government Expenditure granger cause investment. Inflation Rate granger cause Exchange Rate and vice versa. Granger Causality again runs unidirectionally from interest rate to inflation rate. 


\subsection{Error Correction Model Estimation(s)}

Table 4. Estimates of Error Correction Model (ECM)

Dependent Variable: Investment

\begin{tabular}{llll}
\hline Variable & Coefficient & Standard Error & T - Statistic \\
\hline ECM & -0.67462 & 0.12582 & -0.53620 \\
\hline D(EXR(-1)) & -0.464678 & 0.21188 & -2.19315 \\
\hline D(GOVEX (-1) & 2.6206 & 9.806 & 0.26784 \\
\hline D(INF (-1) & 0.45977 & 0.37793 & -1.21642 \\
\hline D(INT (-1)) & -1.145155 & 0.90407 & -1.26666 \\
\hline D(INV(-1)) & -0.000178 & 0.00034 & -0.52891 \\
\hline C & 1.79885 & 2.602867 & 0.069110 \\
\hline R- Square & 0.561621 & log likelihood & -93.43296 \\
Adj. R. Square & 0.386269 & Akaike AIC & 9.130269 \\
Sum Sq. Resides & 6292230 & Schwarz SC & 9.477419 \\
S.E Equation & 20.48126 & Mean dependent & 6.640455 \\
F. Statistic & 3.202824 & 3.D Dependent & 26.14373
\end{tabular}

Source: E-view 7.1 Researchers' computation 2015

The error correction term (ECM) lagged one period with coefficient of -0.67462 is appropriately signed and significant. Thus, a short run disequibrium in investments is corrected at a speed approximately $67 \%$ per annum.

\subsection{Test of Hypotheses (Individual Test of Significance)}

Table 5. OLS estimation result

\begin{tabular}{|c|c|c|c|c|}
\hline \multicolumn{5}{|c|}{$\begin{array}{l}\text { Method: Least Squares } \\
\text { Date: } 07 / 05 / 15 \quad \text { Time: } 15: 43 \\
\text { Sample: } 1990 \quad 2013 \\
\text { Included observations: } 24\end{array}$} \\
\hline Variable & Coefficient & Std. Error & t-Statistic & Prob. \\
\hline $\mathrm{C}$ & 6242127 & 29971.44 & 2.082691 & 0.0510 \\
\hline EXR & -271.9027 & 136.9930 & -1.984793 & 0.0618 \\
\hline GOVEX & 0.030900 & 0.004628 & 6.676086 & 0.0000 \\
\hline INF & -49.23616 & 265.2450 & -0.185625 & 0.8547 \\
\hline INT & -662.6204 & 1056.613 & -0.627118 & 0.5380 \\
\hline R-squared & 0.777353 & Mean dependent var & & 57591.83 \\
\hline Adjusted R-squared & 0.730480 & S.D. dependent var & & 39137.60 \\
\hline S.E. of regression & 20318.40 & Akaike info criterion & & 22.85949 \\
\hline Sum squared resid & $7.84 \mathrm{E}+09$ & Schwarz criterion & & 23.10492 \\
\hline Log likelihood & -269.3139 & Hannan-Quinn criter. & & 22.92461 \\
\hline F-statistic & 16.58423 & Durbin-Watson stat & & 1.668659 \\
\hline Prob(F-statistic) & 0.000005 & & & \\
\hline
\end{tabular}

Source: E-view 7\% Researcher's computation 2015. 
In testing for the contribution of the individual explanatory variables to the level of investment in Nigeria (as earlier stated in our hypotheses), the student t-test is adopted. (See Table 6).

Table 6. Macroeconomic individual effects on investment (t-statistic)

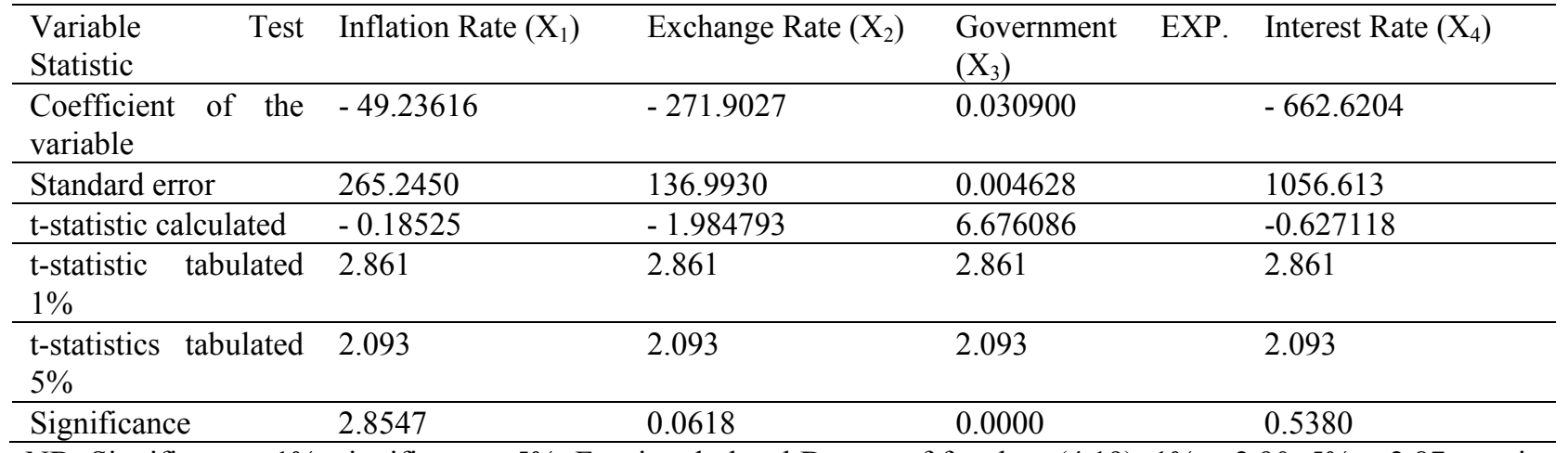

NB: Significant at $1 \%$, significant at $5 \%$, F-ratio tabulated Degree of freedom (4.19); $1 \%=2.90,5 \%=2.87$, t-ratio DF (19) $1 \%=2.861,5 \%=2.093$.

Source: E-view 7.1 Researchers' Computation 2015

From Table 6 above, only government expenditure turned out to be a significant contributor to the level of investment in Nigeria since the t-statistic calculated (6.676086) is greater than the t-tabulated $(2.845,2.086)$ at both $1 \%$ and $5 \%$ level of significance.

\subsection{Discussion of Results}

The time series data were subjected to stationarity test using Augmented Dickey Fuller (ADF) Unit root. The ADF revealed that all the macroeconomic variables were stationary at first difference 1(1).

The R-Squared of $0.777353(77.73 \%)$ is an indication of a strong relationship between the level of investments in Nigeria and the exogenous variables (Inflation, Exchange Rate, Government Expenditure and Interest Rates). The adjusted R. Squared $=0.730480$ shows that the exogenous variables accounts for $73 \%$ changes in investments. This makes the model a good one.

Auto-Correlation was tested using the Durbin - Watson Statistic The Durbin Watson value $=1.668659$ depicts that auto correlation is weak or non-existence of severe auto correlation.

The joint test carried out using the F-ratio revealed that F-Calculated (16.58423) > than the table value $\left(\mathrm{F}_{0} .05,1920\right.$ $=2.90$ ). In other words, the selected determinants have a significant impact and relationship with the level of investment in Nigeria. This confirms the long-run dynamic parsimonious error correction results that is appropriately signed.

The Johansen Co-integration test established the existence of long-run relationship between investments and the identified determinants (Inflation rate, Exchange rate, Government Expenditure and Interest rates). Similarly, the Pairwise granger causality test result shows government expenditure granger cause investments and inflation rate granger cause exchange rate (vice-versa). Also, causality runs uni-directionally from interest rate to inflation rate.

The model equation is therefore specified as: $\mathrm{INV}_{\mathrm{t}}=6242.27-49.236161 \mathrm{nf}_{\mathrm{t}}-271.9027 \mathrm{EXR}_{\mathrm{t}}+0.030900 \mathrm{GOVEX}_{\mathrm{t}}-$ 662.6204INT .

Inflation rate is expected theoretically to be negatively related to investment. This is due to the fact that as inflation rate increase, the value of economic activity reduces, performance drops and ultimately reduces investment. The model revealed an inverse relationship between inflation rate and level of investment.

In the test, the negative and insignificant impact shown by inflation rate can be attributed to macroeconomic instability. This entails those enterprises in Nigeria responds to higher prices of goods and services by increasing output, so as to take advantage of soaring prices and instability. This result conforms with the findings of Acosta (2005).

A higher level of exchange rate reduces investment in the sense that a devaluation of nation's currency means a fall in the real income of the economy. This reduces productive capacity, increases the real cost of purchasing imported 
capital goods, which will eventually lead to a decline in the level of investment. The model equation is in line with the above assertion.

However, the individual test depicts that exchange rate has insignificant impact on the level of investment in the Nigeria economy. This may not be far from the fact that groups, firms and individuals alike finds it difficult to operate as a result of the continuous depreciation of the naira which makes importation of inputs more expensive. No matter how devalued the naira is, the level of importation is still high. This is in tandem with the findings of Ayeni (2014) and Sajid and Sarfraz (2008). According to Ayeni (2014), this is due to the fact that other factors that inhibit investment are much more complex than the exchange rate in Nigeria.

Government expenditures have positive relationship with the level of investment while interest rates have negative relationship with the latter. The effect of interest rate on investment is expected to be negative. This is because as the interest rate (lending rates) increases, it deters prospective investors, makes the cost of borrowing costly and the resultant outcome will be decline/fall in level of investment undertaken.

From the test of the hypotheses, the test revealed negative and insignificant impact shown by interest rates. As earlier mentioned, high interest rates discourages the tendency to borrow. This is because despite all efforts to encourage investment, the interest rate has continued to remain high in Nigeria. For sometimes, the Monetary Policy Rate (MPR) has been maintained at $12 \%$ or little above by Central Bank of Nigeria (CBN). This may or may not have taken into cognizance investment trends. These findings are in line with De-Gregio (2009) empirical findings and also can be explained by the fact that in Nigeria, interest rate is often manipulated and imposed on the borrowers. In other words, interest rate in Nigeria is highly regulated. The double digit rate favours mostly buying and selling rather than investment in real assets.

The positive relationship shown by government expenditure, with level of investment was validated by the formulated hypotheses. This shows that government increased expenditure in recent times have to a greater extent encouraged investment and hence the need to sustain the trend. This is in conformity with the findings of Elbadawi (1996). Investment stimulates economic growth while government expenditure spurs investment.

\section{Conclusion}

This paper examined the determinants of investment in Nigeria: an empirical approach (1990-2013). It identified and investigated these determinants as well as the direction of causality, relationship and impact between the variables and level of investment in Nigeria. The empirical results obtained from Pairwise granger causality, Johansson co-integration and OLS estimation revealed that the entire explanatory variables do meet the apriori expectation. Also, investment in Nigeria has not been encouraged a great deal given the fact that only one of the four selected explanatory variables (government expenditure) exerts a significant effect on the level of Investment in Nigeria.

Therefore, the policy implication of these finding for stakeholders and policy makers include: government should review its policies on investments and pay more attention to its determinants, invest more of its resources in the provision of infrastructure which will increase output, reduce inflation, interest rate and exchange rate fluctuations. They are essential ingredients for boosting investments in Nigeria. Monetary authorities should also find ways of determining the rate at which interest should be maintained to encourage borrowing for investment purposes and exchange rate policies should consider the necessity of price and interest rate stability.

\section{References}

Acosta, P., \& Loza, A. (2005). Short and long Run Determinants of Private Investment in Argentina. Champaign: University of Illinois.

Adofu, I. (2010). Accelerating Economy Growth in Nigeria: The Role of FDI. Research Journal of Economic Theory.

Ajaikaiye, D. O. (2002). Economic Development in Nigeria. A Review of Experience During 1980s. Niger Monograph Services, 1.

Ali, M., \& Mshelia A. (2007). Investment and Nigeria's Economic Growth. Journal of Nigeria Economic Society.

Ayeni, R. K. (2004). Macroeconomic Determinants of private Sector Investment - An Ardl Approach: Evidence from Nigeria. Global Advanced Research Journals, 3.

Bage, C. (2003). The Performance and Future Allocation of Credit to Selected Sectors in Nigerian Economy. CBN Economic and Financial Review, 34.

Bakare, A. S. (2013). Investment Climate and the Performance of Industrial Sector in Nigeria. International Journal of Academic Research in Business and Social Sciences.

CBN. (2003). Annual Report and Statement of Account. 
De-Gregorio, J. (2009). Global Confidence Crisis-The Value of Waiting and the Coordination Failure Revisited. Santiago. Central Bank of Chile.

Donwa, P., \& Agbontaen, O. O. (2010). The Trends and Dynamics of the Determinants of Investment in Nigeria. International Review of Business Research Papers, 6(6).

Elbadawi, I. (1996). Interest rate and Economic Growth in Africa. Washington. World Bank Papers.

Iyoha, M. A. (1998). Rekindling Investment for Economic Development in Nigeria. The Macroeconomic Issues. CBN Economic and Financial Review.

Johansson, J. (2002). Causes of high Inflation in Nigeria. NDIC Quarterly.

Mouawiya, Al-Awad. (2005). Inflation and Investment in Development Countries. Journal of Economic Literature Classification.

Muhammad, H., \& Mohammed, N. (2004). Determinants of Interest Rate Spread in Nigeria: An Empirical Investigation. NDIC Quarterly.

Nnanna, O. J., Englama, A., \& Odoko, F. O. (2004). Finance, Investment and Growth in Nigeria. Abuja. Kas Art Services.

Okereke, L. C. (2000). Managerial Accounting and Control: A Professional Approach. The Accountant.

Sajid, \& Sarfraz M. (2008). Saving and Economic Growth in Pakistan: An Issue of Causality. Pakistan Economic and Social Review, 64.

Serven, P., \& Solinano. (2000). Growth in Development Strategies. International Review of Business Research Papers.

Vaish, A. S. (2007). Macroeconomic Theory. India: McGraw Publishers.

\section{APPENDIX I}

\begin{tabular}{llllll}
\hline YEAR & $\begin{array}{l}\text { INVESTMENT } \\
\text { N'm }\end{array}$ & INFR & EXR & $\begin{array}{l}\text { GOVEX } \\
\text { N'm }\end{array}$ & INTR \\
\hline 1990 & $40,121.31$ & 7.8 & 8.04 & $20,049.30$ & 27.7 \\
\hline 1991 & $39,968.52$ & 12.195 & 9.91 & $27,023.70$ & 20.8 \\
\hline 1992 & $38,771.57$ & 44.57 & 17.3 & $37,060.60$ & 31.2 \\
\hline 1993 & $44,973.00$ & 57.14 & 22.05 & $44,180.90$ & 36.09 \\
\hline 1994 & $40,404.20$ & 57.42 & 21.89 & $55,916.00$ & 21 \\
\hline 1995 & $29,820.29$ & 72.73 & 81.8 & $77,895.50$ & 20.79 \\
\hline 1996 & $35,216.28$ & 29.29 & 8.2 & $83,987.08$ & 20.86 \\
\hline 1997 & $38,329.17$ & 10.67 & 82 & $92,687.00$ & 23.32 \\
\hline 1998 & $36,390.66$ & 7.86 & 84 & $143,168.80$ & 21.34 \\
\hline 1999 & $35,325.93$ & 6.62 & 93.95 & $167,896.00$ & 27.19 \\
\hline 2000 & $41,342.64$ & 6.94 & 102.1 & $359,670.60$ & 21.55 \\
\hline 2001 & $6,331.64$ & 18.87 & 111.93 & $596,956.40$ & 21.34 \\
\hline 2002 & $7,936.78$ & 12.88 & 121 & $724,537.20$ & 30.19 \\
\hline 2003 & $12,991.61$ & 14.03 & 129.3 & $921,159.70$ & 22.88 \\
\hline 2004 & $44,443.72$ & 15 & 133.5 & $1,125,057.00$ & 20.82 \\
\hline 2005 & $39,795.29$ & 17.86 & 131.66 & $1,478,585.40$ & 19.49 \\
\hline 2006 & $63,428.72$ & 8.22 & 128.65 & $1,586,796.60$ & 18.7 \\
\hline 2007 & $89,896.86$ & 5.42 & 134.05 & $1,116,138.90$ & 19.36 \\
\hline 2008 & $89,244.50$ & 11.58 & 132.37 & $3,021,602.24$ & 18.7 \\
\hline 2009 & $120,273.64$ & 12.54 & 132.6 & $2,776,912.95$ & 22.62 \\
\hline 2010 & $142,316.45$ & 13.72 & 148.68 & $3,266,234.72$ & 22.51 \\
\hline 2011 & $126,942.84$ & 10.8 & 146.2 & $3,542,001.15$ & 22.42 \\
\hline 2012 & $101,699.74$ & 12.2 & 150.2 & $3,844,925.84$ & 24.65 \\
\hline 2013 & $116,238.63$ & 10.16 & 156 & $4,023,412.64$ & 24.94 \\
\hline S0 & & & &
\end{tabular}

Source: Central Bank of Nigeria 2013. 